\title{
NONLOCAL IN TIME MODEL OF MATERIAL DAMPING IN COMPOSITE STRUCTURAL ELEMENTS DYNAMIC ANALYSIS
}

\author{
Vladimir N. Sidorov ${ }^{1,2}$, E lena. S. B adina ${ }^{1,2,3}$, Elena P. Detina ${ }^{2}$ \\ ${ }^{1}$ Russian University of Transport (MIIT), M oscow, RUSSIA \\ ${ }^{2} \mathrm{~N}$ ational Research M oscow State U niversity of Civil Engineering, M oscow, RUSSIA \\ ${ }^{3}$ Institute of A pplied M echanics of Russian A cademy of Sciences, M oscow RUSSIA
}

\begin{abstract}
In this paper the problem of numerical simulation of composite bending elements dynamic considering internal (material) damping. For this purpose the nonlocal in time damping model, called damping with memory, is proposed as an alternative to the classic local K elvin-V oigt model. Damping with memory makes damping forces not only dependent on the instant value of the strain rate, but also on the previous history of the vibration process. Since finite element analysis is the most common method of structural anal ysis, the nonlocal damping model is integrated into FEA algorithm. The FEA dynamic equilibrium equation is solved using the explicit scheme. The damping matrix was developed using the stationary full energy requirement. One-dimensional nonlocal in time model was implemented in MATLAB software package. The results of three-dimensional numerical simulation of the composite beam vibration obtained in SIM ULIA A baqus were used for model calibration. The obtained results were compared to the results based on classic K elvin-V oight damping model.
\end{abstract}

Keywords: material damping, nonlocal damping, numerical simulation, finite element analysis.

\section{НЕЛОКАЛЬНАЯ ВО ВРЕМЕНИ МОДЕЛЬ ДЕМПФИРОВАНИЯ МАТЕРИАЛА ПРИ ДИНАМИЧЕСКОМ РАСЧЁТЕ КОМПОЗИТНЫХ ЭЛЕМЕНТОВ СТРОИТЕЛЬНЫХ КОНСТРУКЦИЙ}

\author{
В.Н. Сидоров ${ }^{1,2}$, Е.С. Бадьина ${ }^{1,2,3}$, Е.П. Детина ${ }^{2}$ \\ ${ }^{1}$ Российский университет транспорта (МИИТ), г. Москва, РОССИЯ \\ ${ }^{2}$ Национальный исследовательский Московский государственный строительный университет, \\ г. Москва, РОССИЯ \\ ${ }^{3}$ Институт прикладной механики Российской академии наук, г. Москва, РОССИЯ
}

\begin{abstract}
Аннотация: В настоящей работе рассматривается задача численного динамического расчёта изгибаемых элементов конструкций из композитных и нано- материалов с моделированием их демпфирующих свойств, вызываемых внутренним трением в материале. С этой целью нелокальная во времени модель демпфирования материала, называемая демпфированием с памятью, предлагается как альтернатива классической локальной модели КельвинаФойгта. При таком подходе силы демпфирования считаются зависящими не только от мгновенного значения скоростей деформаций в рассматриваемый момент времени, но и от значений скоростей деформаций на предыдущих стадиях колебательного процесса. Поскольку метод конечных элементов (МКЭ) является наиболее предпочтительным численным методом анализа механических систем, нелокальная модель демпфирования интегрирована в алгоритм этого метода. Уравнение равновесия конструкции в движении МКЭ решается по явной схеме. Матрица демпфирования получена из условия стационарности полной энергии деформирования движущейся механической системы. Одномерная нелокальная во времени модель была реализована в программном комплексе MATLAB. Для калибровки модели были использованы результаты трехмерного численного моделирования колебаний композитной балки, полученные в SIMULIA Abaqus. Полученные результаты были сопоставлены с результатами, основанными на классической модели демпфирования Кельвина-Фойгта.
\end{abstract}

Ключевые слова: внутреннее трение, нелокальное демпфирование, численное моделирование, метод конечных элементов. 


\section{INTRODUCTION}

Simulation of the material damping properties is the complicated problem, which still does not have an unambiguous solution [1]. It becomes especially sophisticated speaking of materials with complicated internal structure, such as composite and nano-materials. In such cases special hypothesis of internal friction are required, flexible and controllable enough to describe damping properties of the orthotropic or anisotropic material, consisting of two or more phases.

At the same time the damping model have to be not overly complex, so it can be used in applied engineering calculations.

Since the finite element analysis is the most common numerical method used in engineering practice, we felt it worthwhile to develop the internal damping model, that can be simply built in the FEA algorithm.

In this paper nonlocal in time damping model is used as such a flexible model [2].

\section{FINITE ELEMENT EQUILIBRIUM EQUATION WITH INTEGRATED NONLOCAL IN TIME DAMPING MODEL}

In finite element analysis the dynamic equilibrium equation is presented in matrix form [3]:

$$
M \cdot \ddot{\bar{V}}(t)+D \cdot \dot{\bar{V}}(t)+K \cdot \bar{V}(t)=\bar{F}(t)
$$

Here $\overline{\boldsymbol{V}}(\boldsymbol{t})$ - vector of nodes displacements (dot indicates time derivative), $\boldsymbol{K}$ - stiffness matrix of the finite element model, $\boldsymbol{D}$ - damping matrix, $\boldsymbol{M}$ - mass matrix, $\overline{\boldsymbol{F}}(\boldsymbol{t})$ - load vector. For nonlocal in time damping model we consider that damping of the structure at the current time moment $t$ is assumed to be dependent not only on instant value of strain rate at this moment $\dot{\varepsilon}(t)$, but also on the values of strain rates $\dot{\boldsymbol{\varepsilon}}(\boldsymbol{\tau})$ of the previous time history $\tau=0 \div \mathrm{t}$ [4]. The longer is the gap between the two time points the lower is the influence that one of them has on the other.
To simulate the nonlocal in time properties of material damping («damping with memory») equation (1) is represented as:

$$
\begin{aligned}
& M \cdot \ddot{\bar{V}}(t)+D \cdot \int_{0}^{t} G(t-\tau) \cdot \dot{\bar{V}}(\tau) d \tau+ \\
& K \cdot \bar{V}(t)=\bar{F}(t) .
\end{aligned}
$$

Here $\boldsymbol{G}(\boldsymbol{t}-\boldsymbol{\tau})$ is the kernel function that describes the decrease of the strain rate influence at the moment $\boldsymbol{\tau}$ on the damping at the current moment $\boldsymbol{t}$, and it satisfies the normalization requirement:

$$
\int_{0}^{t} G(t-\tau) d \tau=1
$$

In this research the kernel function is constructed on the base of Gauss integral:

$$
\int_{-\infty}^{\infty} e^{-x^{2}} d x=\sqrt{\pi}
$$

that, taking into account the condition (3), can be written as:

$$
G(t-\tau)=\frac{2 \mu}{\sqrt{\pi}} \cdot e^{-\mu^{2}(t-\tau)^{2}}
$$

Here $\boldsymbol{\mu}$ is a parameter, that characterize the level of damping nonlocality in time. It is further called "influence distance".

Assuming that the material damping with memory model depends on values of strain rate, the material damping matrix is obtained according to the requirement of stationary full energy of the vibrating system. The dissipation of energy by a material during deformation of a finite element under the dynamic loads will be represented by a dissipative function:

$$
\Phi_{D}=\frac{1}{2} \chi \dot{\varepsilon}^{2},
$$

where $\dot{\varepsilon}$ - strain rate, $\chi$ - coefficient that defines material viscosity. It can be obtained as: 


$$
\chi=E \cdot t_{\kappa} .
$$

Here $\boldsymbol{E}$ - is Y oung modulus. Time delay $\boldsymbol{t}_{\boldsymbol{\kappa}}$ can be determined through the damping coefficient (critical fraction) $\xi[5]$ :

$$
t_{\kappa}=\frac{2 \xi}{\omega} .
$$

Here $\omega$ - is the first natural frequency of the system.

Energy dissipation through the material of the whole system can be presented as summation of energy dissipations through each finite el ement:

$$
\Phi_{D}=\sum_{i-1}^{N} \Phi_{D i}
$$

where $\mathrm{i}$ - finite el ement number $(\mathrm{i}=1,2, \ldots, \mathrm{N})$, $\mathrm{N}$ - number of elements in the whole FE computational model.

Here damping matrix is developed for the frame element in bending and tension. In this case energy dissipation through the element material is:

$$
\Phi_{D i}=\frac{1}{2} \int_{l} \chi \dot{\varepsilon}_{a}^{2} A d z+\frac{1}{2} \int_{l} \int_{A} \chi \dot{\varepsilon}_{b}^{2} d A d z
$$

where A - element cross-section area, z longitudinal coordinate, I - element length, $\dot{\varepsilon}_{a}$ tension-induced axial strain rate, $\dot{\varepsilon}_{b}$ - bendinginduced axial strain rate:

Tension-induced axial strain, is [6]:

$$
\varepsilon_{a}=\frac{d u}{d z}
$$

where $\mathrm{u}$ - axial displacement.

Bending-induced axial strain, of for the EulerB ernoulli beam:

$$
\varepsilon_{b}=\frac{1}{\rho} y=\kappa y \approx \frac{d^{2} v}{d z^{2}} y .
$$

Here $\rho$ - radius of curvature of the beam neutral layer, y - distance to the considered beam fiber from its neutral layer, $v$ transverse displacement, $\kappa$ - curvature of the $v$-line in the cross-section with the longitudinal coordinate $z$.

Then:

$$
\begin{aligned}
\Phi_{D i}=\frac{1}{2} A \chi \int_{l} & \left(\frac{d \dot{u}}{d z}\right)^{2} d z \\
& +\frac{1}{2} I \chi \int_{l}\left(\frac{d^{2} v}{d z^{2}}\right)^{2} d z,
\end{aligned}
$$

where I - element cross-section moment of inertia. Within the FEA the axial displacements are approximated inside the beam element with linear shape function $\left[N_{u}\right]=\left[\begin{array}{ll}1-\xi & \xi\end{array}\right]$, and the transverse displacements - with cubic shape function

$$
\left[N_{v}\right]^{T}=\left[\begin{array}{c}
1-3 \xi^{2}+2 \xi^{3} \\
l\left(\xi-2 \xi^{2}+\xi^{3}\right) \\
3 \xi^{2}-2 \xi^{3} \\
l\left(-\xi^{2}+\xi^{3}\right)
\end{array}\right]
$$

$\xi=\frac{Z}{l}$ - is the reduced local Iongitudinal coordinate.

Taking this into account we can transform the expression (13) to:

$$
\begin{aligned}
& \Phi_{D i} \approx \\
& \approx \frac{1}{2} A \chi \int_{0}^{1}\left(A_{u}\left[N_{u}\right]\right)^{T} \cdot A_{u}\left[N_{u}\right] \cdot \dot{u}_{i} \cdot \dot{u}_{i} l d \xi \\
& +\frac{1}{2} I \chi \int_{0}^{1}\left(A_{v}\left[N_{v}\right]\right)^{T} \cdot A_{v}\left[N_{v}\right] \cdot \dot{v}_{i} \cdot \dot{v}_{i} l d \xi .
\end{aligned}
$$

Here $\dot{u}_{i}=\left(\begin{array}{c}\dot{u}_{0} \\ \dot{u}_{l}\end{array}\right)$ and $\dot{v}_{i}=\left(\begin{array}{c}\dot{v}_{0} \\ \dot{\varphi}_{0} \\ \dot{v}_{l} \\ \dot{\varphi}_{l}\end{array}\right)$ are axial and bending nodal displacements strain rate vectors, 
where $\dot{v}_{0}$ and $\dot{v}_{l}$ are transverse strain rates, and $\dot{\varphi}_{0}$ and $\dot{\varphi}_{l}$ - rotation strain rates.

$\ln (14) A_{u}=\frac{d}{l \cdot d \xi}$ and $A_{v}=\frac{d^{2}}{l^{2} \cdot d \xi^{2}}$.

Participation (14) in the stationarity requirements of the full energy change:

$$
\frac{\partial \Phi_{D}}{\partial \dot{v}}=0
$$

gives us a $D \cdot \dot{\bar{V}}$ member in the equilibrium equation in motion.

System damping matrix $D$ is obtained by topological summation of element damping matrices $D_{i}$ :

$$
\begin{aligned}
& D_{i}= \\
& =A \chi \int_{0}^{1}\left(A_{u}\left[N_{u}\right]\right)^{T} \cdot A_{u}\left[N_{u}\right] l d \xi \\
& +I \chi \int_{0}^{1}\left(A_{v}\left[N_{v}\right]\right)^{T} \cdot A_{v}\left[N_{v}\right] l d \xi
\end{aligned}
$$

In this way $D_{i}$ matrix for the plane frame elements is:

$\mathbf{D}_{\mathbf{i}}=\chi \cdot$\begin{tabular}{|c|c|c|c|c|c|}
\hline$\frac{\mathbf{A}}{\mathbf{I}}$ & 0 & 0 & $-\frac{\mathbf{A}}{\mathbf{I}}$ & 0 & 0 \\
\hline 0 & $\frac{12 \cdot \mathbf{J}}{\mathbf{I}^{3}}$ & $\frac{6 \cdot \mathbf{J}}{\mathbf{I}^{2}}$ & 0 & $-\frac{12 \cdot \mathbf{J}}{\mathbf{I}^{3}}$ & $\frac{6 \cdot \mathbf{J}}{\mathbf{I}^{2}}$ \\
\hline 0 & $-\frac{6 \cdot \mathbf{J}}{\mathbf{I}^{2}}$ & $\frac{4 \cdot \mathbf{J}}{\mathbf{I}}$ & 0 & $-\frac{6 \cdot \mathbf{J}}{\mathbf{I}^{2}}$ & $\frac{2 \cdot \mathbf{J}}{\mathbf{I}}$ \\
\hline$-\frac{\mathbf{A}}{\mathbf{I}}$ & 0 & 0 & $\frac{\mathbf{A}}{\mathbf{I}}$ & 0 & 0 \\
\hline 0 & $-\frac{12 \cdot \mathbf{J}}{\mathbf{I}^{3}}$ & $-\frac{6 \cdot \mathbf{J}}{\mathbf{I}^{2}}$ & 0 & $\frac{12 \cdot \mathbf{J}}{\mathbf{I}^{3}}$ & $-\frac{6 \cdot \mathbf{J}}{\mathbf{I}^{2}}$ \\
\hline 0 & $\frac{6 \cdot \mathbf{J}}{\mathbf{I}^{2}}$ & $\frac{2 \cdot \mathbf{J}}{\mathbf{I}}$ & 0 & $-\frac{6 \cdot \mathbf{J}}{\mathbf{I}^{2}}$ & $\frac{4 \cdot \mathbf{J}}{\mathbf{I}}$ \\
\hline
\end{tabular}

\section{NUMERICAL EXAMPLE}

A s a simple example we consider GFRP beam with the fixed ends made of orthotropic thermoset vinyl ester class 1 GFRP under instantly applied distributed load $q=10 \mathrm{kN} / \mathrm{m}$. The beam is $12 \mathrm{~m}$ long and has a rectangular cross-section $20 \times 30 \mathrm{~cm}$. The characteristics of the material obtained experimentally in $[7,8,9]$.

To solve the dynamic equilibrium equation, the method of the central differences is used [Бате]. In this case, the first and second order time derivatives of the displacement vector $\bar{V}(t)$ participating in (1) and (2) are approximated by central finite differences. Then the equation (1), obviously, takes the following form:

$$
\begin{gathered}
\frac{1}{\Delta t^{2}} \cdot M \cdot\left(\bar{V}_{i+1}-2 \bar{V}_{i}+\bar{V}_{i-1}\right)+ \\
+\frac{1}{2 \cdot \Delta t} \cdot D \cdot\left(\bar{V}_{i+1}-\bar{V}_{i-1}\right)+ \\
+K \cdot \bar{V}(t)=\bar{F}_{i} .
\end{gathered}
$$

Here $\mathrm{i}=1,2,3, \ldots \quad$ - number of the considered moment in time $t, \Delta t$ - time increment.

In order to replace the classic damping model in (16) with the damping model with memory, at first we represent the central difference in the second term on the left-hand side of equation (16), which is responsible for damping, as average of the «forward» and «backward» differences:

$$
\begin{gathered}
\frac{1}{\Delta t^{2}} \cdot M \cdot\left(\bar{V}_{i+1}-2 \bar{V}_{i}+\bar{V}_{i-1}\right)+ \\
+\frac{1}{2 \cdot \Delta t} \cdot D \cdot\left(\bar{V}_{i}-\bar{V}_{i-1}\right)+ \\
+\frac{1}{2 \cdot \Delta t} \cdot D \cdot\left(\bar{V}_{i+1}-\bar{V}_{i}\right)+ \\
+K \cdot \bar{V}(t)=\bar{F}_{i} .
\end{gathered}
$$

The term with the «backward» difference is replaced by nonlocal numerical operator:

$$
\begin{aligned}
& \frac{1}{2 \cdot \Delta t} \cdot D \cdot\left(\bar{V}_{i}-\bar{V}_{i-1}\right) \rightarrow \\
& \rightarrow \frac{D}{2} \sum_{j=1}^{i} \bar{G}(i, j)\left(\bar{V}_{j}-\bar{V}_{j-1}\right),
\end{aligned}
$$

where $\mathrm{i}$ - number of the time step which is corresponding to the considered time moment $t$, 
$\mathrm{t}=\Delta t \cdot i, \quad \tau=\Delta \mathrm{t} \cdot \mathrm{j}, \quad \mathrm{j}=1,2, \ldots, \mathrm{i}-$ number of the time step when calculating the kernel $\bar{G}(i, j)$.

$\bar{G}(i, j)$ is the discrete analogue of $G(t-\tau)$ kernel, which for the error function (5) is calculated as follows:

$$
\bar{G}(i, j)=\frac{2 \mu}{\sqrt{\pi}} \cdot e^{-\mu^{2}\left(t-\left(\tau-\frac{\Delta t}{2}\right)\right)^{2}} .
$$

A fter the described transformations equation (17) can be written as:

$$
\begin{gathered}
\frac{1}{\Delta t^{2}} \cdot M \cdot\left(\bar{V}_{i+1}-2 \bar{V}_{i}+\bar{V}_{i-1}\right)+\frac{D}{2} \cdot \bar{Z}+ \\
+\frac{1}{2 \cdot \Delta t} \cdot D \cdot\left(\bar{V}_{i+1}-\bar{V}_{i}\right)+ \\
+K \cdot \bar{V}(t)=\bar{F}_{i}
\end{gathered}
$$

\section{Where}

$$
\begin{gathered}
\bar{Z}=\sum_{j=1}^{i} \frac{2 \mu}{\sqrt{\pi}} e^{-\mu^{2}[t-(\tau-\Delta t / 2)]^{2}} \\
\cdot\left(V_{j}-V_{j-1}\right) .
\end{gathered}
$$

The influence distance $\mu$ determine the nonlocality level in element material. The higher is $\mu$, the closer is the damping model to the classic local one (fig. 1).

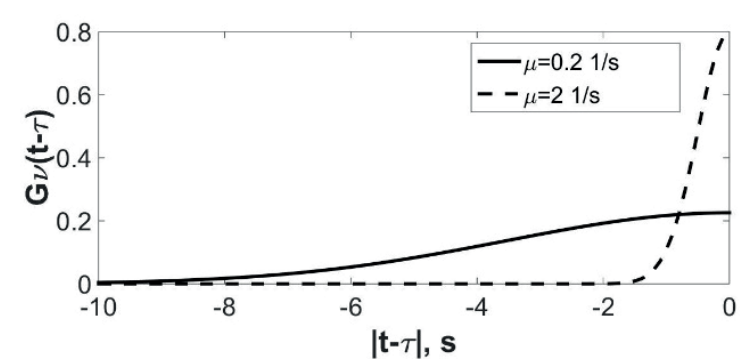

Figure 1. Error kernel functions for different influence distance parameters $\mu$

Transform (20) to the computational scheme for the step-by-step calculating of $\bar{V}_{i+1}$ using the vectors $\bar{V}_{i}$ and $\bar{V}_{i-1}$, which are calculated on the previous increments $i$ and $i-1$ :

$$
\begin{aligned}
& \bar{V}_{i+1}=Q \cdot \bar{F}_{i}-Q_{1} \cdot \bar{V}_{i}- \\
& Q_{2} \cdot \bar{V}_{i-1}-Q_{3} \cdot \bar{Z}
\end{aligned}
$$

where:

$$
\begin{gathered}
Q=\left(\frac{1}{\Delta t^{2}} M+\frac{1}{2 \cdot \Delta t} D\right)^{-1}, \\
Q_{1}=Q \cdot\left(-\frac{2}{\Delta t^{2}} M-\frac{1}{2 \cdot \Delta t} D+K\right), \\
Q_{2}=\frac{1}{\Delta t^{2}} Q \cdot M, \\
Q_{3}=\frac{1}{2} Q \cdot D .
\end{gathered}
$$

For the first two steps of the simulated vibration process $\mathrm{i}=1,2$ we assume $\bar{V}_{1}=0$ and $\dot{\bar{V}}_{1}=$ $\frac{\bar{V}_{2}-\bar{V}_{1}}{\Delta t}=0$ as the initial conditions.

The main problem of all nonlocal models [10, 11,12 ] is obtaining the value of the influence distance, which characterizes the nonlocal damping properties of the material. The solution of this problem with regard to damping model nonlocal in space was proposed in [13]. In that paper $\mu$ was determined using the least squares method based on the numerical simulation data. Likewise, here the calibration of the nonlocal in time damping model was implemented based on the results of the numerical simulation of threedimensional finite element beam vibration in SIMULIA Abaqus CAE. The beam computational model was constructed in SIMULIA Abaqus taking into account the orthotropic properties of the material. The determined optimum value of $\mu$ for the beam, that was considered in privious section, is $\mu=$ $0.11 / s$. The displacements of middle section of the beam in time are shown in fig. 2. The solid line shows the displacements of the beam which is obtained using a calibrated nonlocal model, and the dashed curve - using a 3D model built in SIMULIA A baqus. 


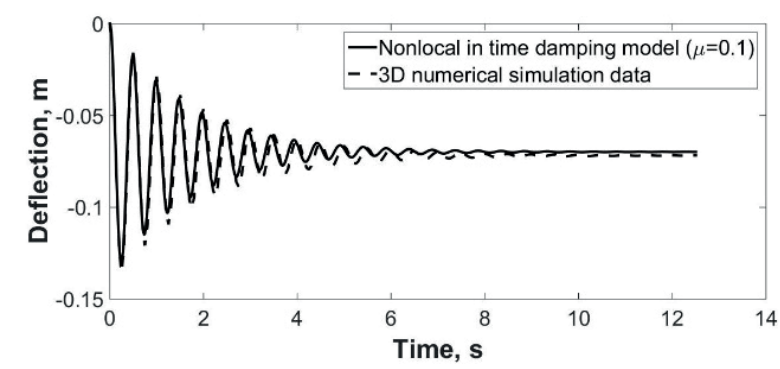

Figure 2. D eflection of the beam obtained with calibrated nonlocal in time damping model in comparison to 3D numerical simulation data

It is obvious, that calibrated nonlocal model allows to obtain much more accurate results, than the K elvin-V oight classic model (fig. 3).

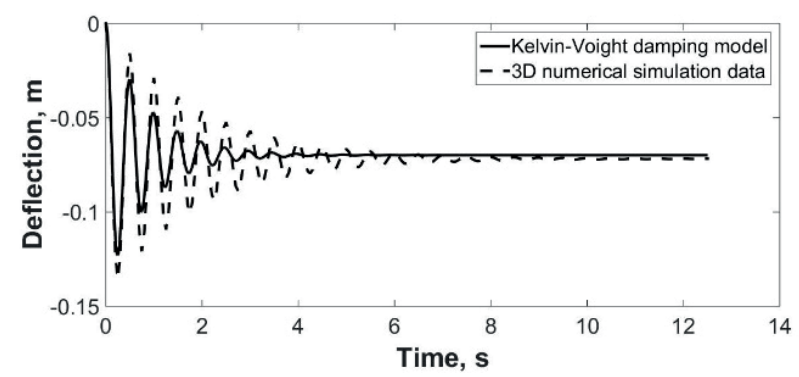

Figure 3. D eflection of the beam obtained with classic local in time damping model in comparison to 3D numerical simulation data

\section{CONCLUSION}

Nonlocal in time damping model presented in this paper makes it possible to quite effectively use one-dimensional models of beam elements in the dynamic analysis of structures which are made of modern composite materials.

The damping matrix, obtained from the stationarity requirements of the energy change, allows to consider internal friction which is the dominant type of damping for the polymer composites.

The damping with memory model can be seamlessly integrated to the FEA algorithm, which makes it applicable to the real-life engineering problems.

\section{ACKNOWLEDGEMENT}

This research has been supported by the R ussian Science Foundation (Project No 21-19-00634).

\section{REFERENCES}

1. Sorokin E.S. On the theory of internal friction during vibrations of elastic systems. 1960, Gosstroyizdat, M oscow, (in R ussian).

2. Sidorov V.N., Badina E.S. Computer Simulation of Structural Vibration Damping With Allowance for Nonlocal Properties, 2020 // International Journal for Computational Civil and Structural Engineering, V olume 16, Issue 4, pp. 84-90.

3. Bathe $\mathbf{K} . \mathbf{J}, \mathbf{W}$ ilson E.L. Numerical methods in finite element analysis. 1976, Prentice Hall, N ew Y ork.

4. Banks H.T., Inman D.J. On damping M echanisms in Beams Journal of Applied M echanics. 1991, 58(3), pp. 716-723.

5. Alexandrov A.V., Potapov V. D., Zylyov V.B. Structural mechanics. In 2 books. Book 2. Dynamic and stability of the elastic systems. 2008, Highschool, Moscow (in Russian).

6. Sidorov V.N. Mechanics of materials. "A rchitechture-S". 2013, M oscow - 395 pp (in Russian).

7. L andherr J.C. Dynamic analysis of a FRP deployable box beam. Master of Applied Science Thesis. Kingston: Queen's U niversity, 2008.

8. L im R.A. Structural monitoring of a $10 \mathrm{~m}$ fibre reinforced polymer bridge subjected to severe damage (Kingston: Queen's U niversity), 2016.

9. Xie A. Development of an FRP Deployable $B$ ridge, M aster of Applied Science Thesis, Department of Civil Engineering, Royal M ilitary College of Canada, 2007.

10. L ei Y ,, Friswell M I. ., Adhikari S. A Galerkin Method for Distributed Systems with Nonlocal Damping Int. Journal of Solids and Structures 43, p. 3381-3400, 2006. 
11. E ringen A.C., Edelen D.G.B., 1972, Nonlocal elasticity. Int J Eng Sci; 10(3): 233-48.

12. Polizzotto C. Nonlocal elasticity and related variational principles. Int J Solids Struct; 2001, 38 (42-43): 7359-80. DOI: 10.1016/S0020-7683(01)00039-7.

13. E.S. Shepitko, V.N. Sidorov. Defining of nonlocal damping model parameters based on composite beam dynamic behaviour numerical simulation results, 2019 // IOP Conf. Series: Materials Science and Engineering 675012056.

\section{СПИСОК ЛИТЕРАТУРЫ}

1. Сорокин Е.С. К теории внутреннего трения при колебаниях упругих систем Москва: Госстройиздат, 1960, 131 с.

2. Sidorov V.N., Badina E.S. Computer Simulation of Structural Vibration Damping With Allowance for Nonlocal Properties // International Journal for Computational Civil and Structural Engineering, Volume 16, Issue 4, 2020 - C. 84-90.

3. Bathe K.J., Wilson E.L. Numerical methods in finite element analysis. Prentice Hall, N ew Y ork, 1976.

4. Banks H.T., Inman D.J. On damping Mechanisms in Beams Journal of Applied M echanics 58(3), 1991, pp. 716-723.

5. Александров А.В., Потапов В.Д., Зылёв В.Б., Строительная механика. В 2-х книгах. Книга 2. Динамика и устойчивость упругих систем. Издательство: Высшая школа, 2008.

6. Сидоров В.Н. Сопротивление материалов. Издательство «АрхитектураC», 2013, - 395 стр.

7. Landherr J.C. Dynamic analysis of a FRP deployable box beam. Master of A pplied Science Thesis. Kingston: Queen's University, 2008

8. Lim R.A. Structural monitoring of a $10 \mathrm{~m}$ fibre reinforced polymer bridge subjected to severe damage (Kingston: Queen's University), 2016.

9. Xie A. Development of an FRP Deployable B ridge, Master of A pplied Science Thesis, Department of Civil Engineering, Royal M ilitary College of Canada, 2007

10. Lei Y., Friswell M.I., Adhikari S. A Galerkin Method for Distributed Systems with Non-local Damping Int.J ournal of Solids and Structures 43, 2006, pp. 33813400.

11. Eringen A.C., Edelen D.G.B. Nonlocal elasticity. Int J Eng Sci;10(3):233-48. 1972.

12. Polizzotto C. Nonlocal elasticity and related variational principles. Int J Solids Struct; 2001, 38(42-43):7359-80. DOI: 10.1016/S0020-7683(01)00039-7

13. E.S. Shepitko, V.N. Sidorov. Defining of nonlocal damping model parameters based on composite beam dynamic behaviour numerical simulation results. 2019 // IOP Conf. Series: Materials Science and Engineering 675012056
Vladimir N. Sidorov, Corresponding Member of Russian Academy of Architecture and Construction Science, Professor, Dr.Sc, Rectorate Counselor, Head of the Department of Computer Science and Applied Mathematics, National Research University Moscow State University of Civil Engineering, Professor of «Building Structures, Buildings and Facilities» Department, Institute of Railway Track, Construction and Structures, Russian University of Transport (MIIT), Professor of Department «Engineering Structures and Numerical Mechanics», Perm National
Research Polytechnic University; 127994, Russia, Moscow, Obraztsova st., 9, b. 9, phone: +74956814381, e-mail: sidorov.vladimir@gmail.com.

Elena S. Badina, Ph.D, Associate Professor of «Computer Aided Design» Department, Institute of Railway Track, Construction and Structures, Russian University of Transport (MIIT), Senior Researcher at the Scientific and Educational Center for Computer Modeling of Unique Buildings, Structures and Complexes of the Moscow State 
Nonlocal in Time Model of Material Damping in Composite Structural Elements Dynamic Analysis

University of Civil Engineering, Senior Researcher at the Department of Mechanics of Structured and Heterogeneous Environment of the Institute of Applied Mechanics of the Russian Academy of Sciences; 127994, Russia, Moscow, Obraztsova st., 9, b. 9, phone: +74956092116, e-mail: shepitko-es@mail.ru.

Elena P. Detina, Research Engineer, Department of Analytical Fundamental Scientific Research on the Dynamics of Building Structures, Scientific and Educational Center for Computer Modeling of Unique Buildings, Structures and Complexes (REC KM), Lecturer at the Department of Applied Mathematics and Informatics, Moscow State University of Civil Engineering (NRU MGSU); 129337, Russia, Moscow, Yaroslavskoe shosse, 26, phone+74957819988, e-mail: detinaep@mgsu.ru

Сидоров Владимир Николаевич, член-корреспондент PAACH, профессор, доктор технических наук, советник при ректорате, заведующий кафедрой информатики и прикладной математики Национального исследовательского Московского государственного строительного университета, профессор кафедры «Строительные конструкции, здания и сооружения» Института пути, строительства и сооружений Российского университета транспорта (МИИТа); 127994, Россия, г. Москва, ул.
Образцова, д.9, стр. 9, телефон: +74956814381, e-mail: sidorov.vladimir@gmail.com.

Бадьина Елена Сергеевна, кандидат технических наук, доцент кафедры «Системы автоматизированного проектирования» Института пути, строительства и сооружений Российского университета транспорта (МИИТа), старший научный сотрудник Научно-образовательного центра компьютерного моделирования уникальных зданий, сооружений и комплексов Московского государственного строительного университета, старший научный сотрудник Отдела механики структурированной и гетерогенной среды Института прикладной механики Российской академии наук, 127994, Россия, г. Москва, ул. Образцова, д.9, стр. 9 , телефон: +74956092116, e-mail: shepitko-es@mail.ru.

Детина Елена Петровна, инженер-исследователь отдела аналитических фундаментальных научных исследований по динамике строительных конструкций Научно-образовательного центра компьютерного моделирования уникальных зданий, сооружений и комплексов (НОЦ КМ), преподаватель кафедры Прикладной математики и информатики Московского государственного строительного университета (НИУ МГСУ); 129337, Россия, г. Москва, Ярославское шоссе, д. 26, телефон +74957819988, e-mail: detinaep@mgsu.ru 